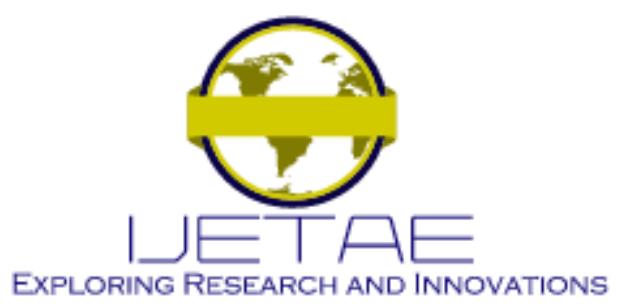

International Journal of Emerging Technology and Advanced Engineering

Website: www.ijetae.com (E-ISSN 2250-2459, Scopus Indexed, ISO 9001:2008 Certified Journal, Volume 11, Issue 10, October 2021)

Manuscript Received: 06 September 2021, Received in Revised form: 02 October 2021, Accepted: 10 October 2021

DOI: $10.46338 /$ ijetae1021_12

\title{
Analysis Model for Identifying Negative Posts Based on Social Media
}

\author{
Ade Febriany ${ }^{1}$, Ditdit Nugeraha Utama ${ }^{2}$ \\ ${ }^{1,2}$ Computer Science Department, BINUS Graduate Program - Master of Computer Science, Bina Nusantara University, \\ Jakarta, Indonesia 11480
}

\begin{abstract}
Cyberbullying is an act that violates where this crime is committed on social media, e.g. the Twitter application. This action is difficult to detect, thus someone has to report the case before detection. Identification of cyberbullying tweets aims to classify tweets containing the bullying content. Several studies gave output results in the identification of whether the tweet is positive or negative, or bully or not. It can be confusing when analyzing the classification results as it only results in two classes. In this research, by using the conception of text mining Naïve Bayes, the model that can categorize into more detail was developed. It does not only categorize the contents are bullying or not, however it can classify the contents into five detail categories. The classification process done based on the dataset and label where the schema to build dataset was proposed scientifically from this study. The contribution of this research is to offer the algorithm to collect and label the Indonesian language dataset and then classify the types of sarcasm, namely animal, psychology and stupidity, disabled person, attitude, and general bullying. The research hypothesis is that analysis from the classification results can be improved by classifying bully content into the five classes. Dataset was collected by the researcher and labelling was done manually based on study literature. The result proves the model can use to classify cyberbullying content in social media with $99.15 \%$ accuracy.
\end{abstract}

Keywords - Social media, Twitter, Analysis Model, Text Mining, Naïve Bayes.

\section{INTRODUCTION}

Information technology in Indonesia have spread to various levels of society. Increasing technological advances cannot be separated from the increasing public need for various information. Current information can be obtained very easily using advanced technology such as the internet. With the internet, people, from all over the world, can exchange the information without being limited by space, time and save costs.
The number of internet users in Indonesia in 2019 reached 171.17 million people, or around 54.86 percent of the total Indonesian people [1]. Of the total internet users, around 150 million Indonesians are active on various social media, ranging from Facebook, Instagram, Twitter, and others. This means that the most of internet users socialize through social media.

Social media is the most popular application among Indonesian internet users. The trend of its users continues to increase significantly, so are the features provided by the social media application developer and are growing. The simple reason that social media is widely used by people is online interaction with practical mobile technology that can be carried everywhere, so that everyone can do it whenever and wherever they are and are free to express any opinion.

Regardless of what happens on social media, crime is an everyday part of what is encountered in the real world. Bullying is a phenomenon that very much occurs in the education system in this country. The devastating effects of this crime of bullying are amplified by the presence of social media. Because social media is not only used by a small number of people, but also by people around the world who have connections and knowledge with the real world.

Most of researchers on detecting cyberbullying content in social media were only classify data into two classes, such as positive or negative, or bully or not bully. It can be confusing when analysing the classification results as it only results in two classes. It can be confusing when analysing the classification results as it only generates two classes while we need clearer categories when content is categorized as bully content.

At this present time, research from collection of texts is a concern of researchers. Many comments or posts are in the form of text that come from social media. 


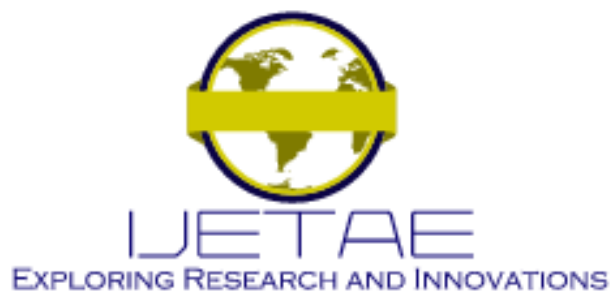

International Journal of Emerging Technology and Advanced Engineering

Website: www.ijetae.com (E-ISSN 2250-2459, Scopus Indexed, ISO 9001:2008 Certified Journal, Volume 11, Issue 10, October 2021)

Posts on social media are central to almost all people's activities and are key influencers of individuals or groups. The result of posts analysis is grouping posts from Twitter into several cyberbully classes which are determined based on the results of the analysis of literature study. In grouping posts into verbal violence classes, text mining has several algorithms. This study is using Naïve Bayes classification. Naïve Bayes algorithm is a simple probabilistic classifier that calculated a set of probabilities by counting the frequency and combinations of values in each dataset. The purpose of this research is to build a model for analysing verbal violence on Bahasa Indonesia (Indonesian language) based on activities in social media and labelling the data by conducting deep analysis of literature studies. The contribution of this research is to offer the algorithm to collect and label the Indonesian language dataset and then classify the types of sarcasm.

\section{RELATED WORKS}

Researchers from texts collected on social media have been done a lot before. The study of [2] used the K-Means and Naive Bayes algorithms to analyse cyberbullying content from Facebook and Twitter content. These sentiments were classified into positive and negative classes. The results of this study indicate that the combination of K-Means and Naïve Bayes obtains slightly lower accuracy than the application of the Naïve Bayes algorithm without the combination with K-Means. The accuracy of the classification results of the Naïve Bayes algorithm was $80.526 \%-82.500 \%$, while the accuracy of the combined results of the Naïve Bayes algorithm and KMeans was $80.323 \%-81.523 \%$ [2].

Another related research has conducted a study detecting cyberbullying content using the Naïve Bayes classification algorithm. The dataset was obtained from news posts from Facebook. The data was classified into a bully and not bully classes. The result obtained based on the classification is about $74 \%$ accuracy [3].

Another related research is analysis by applying data mining to social media. This study focuses on analysing how much cyberbullying was in Indonesia, especially on content on Twitter, and the types of cyberbullying that perpetrators often do to bully.
The data mining process applies weighting calculations using TF-IDF, data validation and classification using the Naïve Bayes algorithm. The classification was divided into positive and negative classes.

The result obtained from the content on Twitter that contain bullying was $86.97 \%$ accuracy and the type of cyberbullying that is most widely used was psychological [4].

A researcher conducts research to identify hateful content on social media. This study conducted trials using the Naïve Bayes classification algorithm and the Support Vector Machine. The dataset used to classify hateful content is obtained from content on Twitter. The data are classified into hate speech, offensive language, and neutral classes. The focus of this research is to perform normalization and foremost to reduce noise but not improve performance. The results of this study were accuracy of between $76.7 \%$ and $93.55 \%$ [5].

Base on the related works from the previous paragraphs, so many researchers process the classification of cyberbullying content into two class, such as positive or negative, or bully or not bully. In case to get the best result to detect cyberbullying content, this research develops a model to classify type of cyberbullying with five types, namely animal, psychology and stupidity, disabled person, attitude and general. The machine learning method that used in this research is Naïve Bayes because it is rapid, and the accuracy is very high. So, this research is to build a model to analyse cyberbullying content on social media through analysis of literature studies. This model is only implemented for single language Indonesia. Because, in the Indonesian language, there are so many sarcastic words or sentences.

\section{RESEARCH METHODOLOGY}

This research steps are starting from literature review studying until model developing. Firstly, literature review studying is performed to enrich our case. As the result of this step is we define the labels and words related to the cyberbullying words (see TABLE 1). 


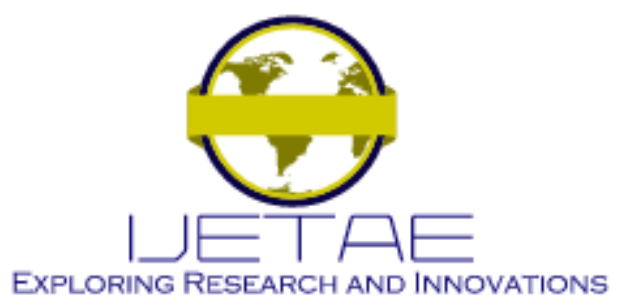

International Journal of Emerging Technology and Advanced Engineering

Website: www.ijetae.com (E-ISSN 2250-2459, Scopus Indexed, ISO 9001:2008 Certified Journal, Volume 11, Issue 10, October 2021)

TABLE 1

THE LABEL USED IN THE MODEL

\begin{tabular}{|c|l|l|l|l|}
\hline No & Label & Description & $\begin{array}{l}\text { Words in Indonesia } \\
\text { (Keyword) }\end{array}$ & Sources \\
\hline 1 & Animal & $\begin{array}{l}\text { Bullying word } \\
\text { related to } \\
\text { animals }\end{array}$ & $\begin{array}{l}\text { Bangsat, anjing, } \\
\text { babi, } \text { monyet, } \\
\text { kunyuk }\end{array}$ & {$[6][7]$} \\
\hline 2 & $\begin{array}{l}\text { Psychology } \\
\text { and } \\
\text { Stupidity }\end{array}$ & $\begin{array}{l}\text { Bullying word } \\
\text { related to } \\
\text { psychology } \\
\text { and stupidity }\end{array}$ & $\begin{array}{l}\text { Goblok, idiot, } \\
\text { geblek, gila, tolol, } \\
\text { sarap, udik, } \\
\text { kampungan }\end{array}$ & {$[6][7]$} \\
\hline 3 & $\begin{array}{l}\text { Disabled } \\
\text { Person }\end{array}$ & $\begin{array}{l}\text { Bullying word } \\
\text { related to } \\
\text { disabled person }\end{array}$ & Buta, budek, jelek & {$[6][7]$} \\
\hline 4 & Attitude & $\begin{array}{l}\text { Bullying word } \\
\text { related to bad } \\
\text { attitude }\end{array}$ & $\begin{array}{l}\text { Setan, iblis, } \\
\text { keparat, gembel, } \\
\text { brengsek, } \\
\text { sompret, bajingan }\end{array}$ & {$[6][7]$} \\
\hline 5 & General & $\begin{array}{l}\text { Bullying word } \\
\text { related to } \\
\text { general } \\
\text { bullying }\end{array}$ & Bejad & {$[6][7]$} \\
\hline
\end{tabular}

The next step is data crawling from Twitter using RapidMiner based on labels and words that has been collected from the previous step. The preparation data is successfully carried out, then data collection is carried out for further preparation as dataset for this study.

Once the data is collected, the construction of the model is carried out. The model is built to give direction to do manual labelling for generating training data. Then, the training data is used to make the decisions based on Naïve Bayes algorithm.

\section{A. Nä̈ve Bayes Classifier}

The Naïve Bayes algorithm is a simple probability classification applying Bayes' theorem. The advantage of this algorithm is that it can estimate what parameters will be used to classify only with a number of training data [8].

The classification of the Naïve Bayes algorithm is calculated with equation (1).

$$
P\left(c_{j} \mid w_{i}\right)=P\left(c_{j}\right) \times P\left(w_{i} \mid c_{j}\right)
$$

The value of $P\left(c_{j}\right)$ is the probability that a category will appear during training.
Equation (2) is used to obtain the value of $P\left(c_{j}\right)$, where $N c_{j}$ is the number of keywords that that belong to the category $c_{j}$ and $N$ is the number of keywords from the training data used.

$$
P\left(c_{j}\right)=\frac{N c_{j}}{N}
$$

The value of $P\left(w_{i} \mid c_{j}\right)$ is the probability of the $i$ word in the $j$ category. This value can be obtained by equation (3), where count $\left(w_{i}, c_{j}\right)+1$ is the number of occurrences of the test $\left(w_{i}\right)$ in the data categorized $\left(c_{j}\right)$ then added by 1 to avoid the value of $0, \sum_{w \in V} \operatorname{count}\left(w, c_{j}\right)$ is the number of occurrences of all words in the category $\left(c_{j}\right)$, while $|V|$ is the total number of words in all categories.

$$
P\left(w_{i} \mid c_{j}\right)=\frac{\operatorname{count}\left(w_{i}, c_{j}\right)+1}{\left(\sum_{w \in V} \operatorname{count}\left(w, c_{j}\right)\right)+|V|}
$$

Calculate $V_{\text {map }}$ to determine the probability of data testing in each class. The calculation of the $V_{\text {map }}$ value can be seen in the equation (4). Where $V$ is set of target classes and $V_{\text {map }}$ is the class argument

$$
V_{\text {map }}=P\left(V_{i}\right) \Pi P\left(w_{i}, c_{j}\right)
$$

\section{RESUlt AND Discussion}

Figure 1 shows the model diagram used to build the model in this research. From the model diagram it shows that one tweet contains one crime indication. One crime indication can be generated for one or more tweets. In one naive bayes classification process, several indications of crime can be generated, while one crime indication can be generated from a single naive Bayes classification process. The class diagram functioned to depict all entities considered in the constructed model like mentioned by [9][10].

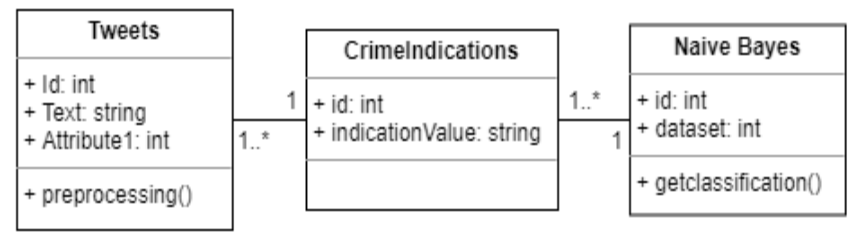

Figure 1: Model's Class Diagram 


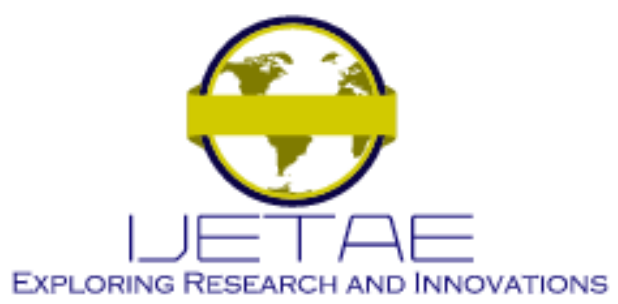

International Journal of Emerging Technology and Advanced Engineering

Website: www.ijetae.com (E-ISSN 2250-2459, Scopus Indexed, ISO 9001:2008 Certified Journal, Volume 11, Issue 10, October 2021)

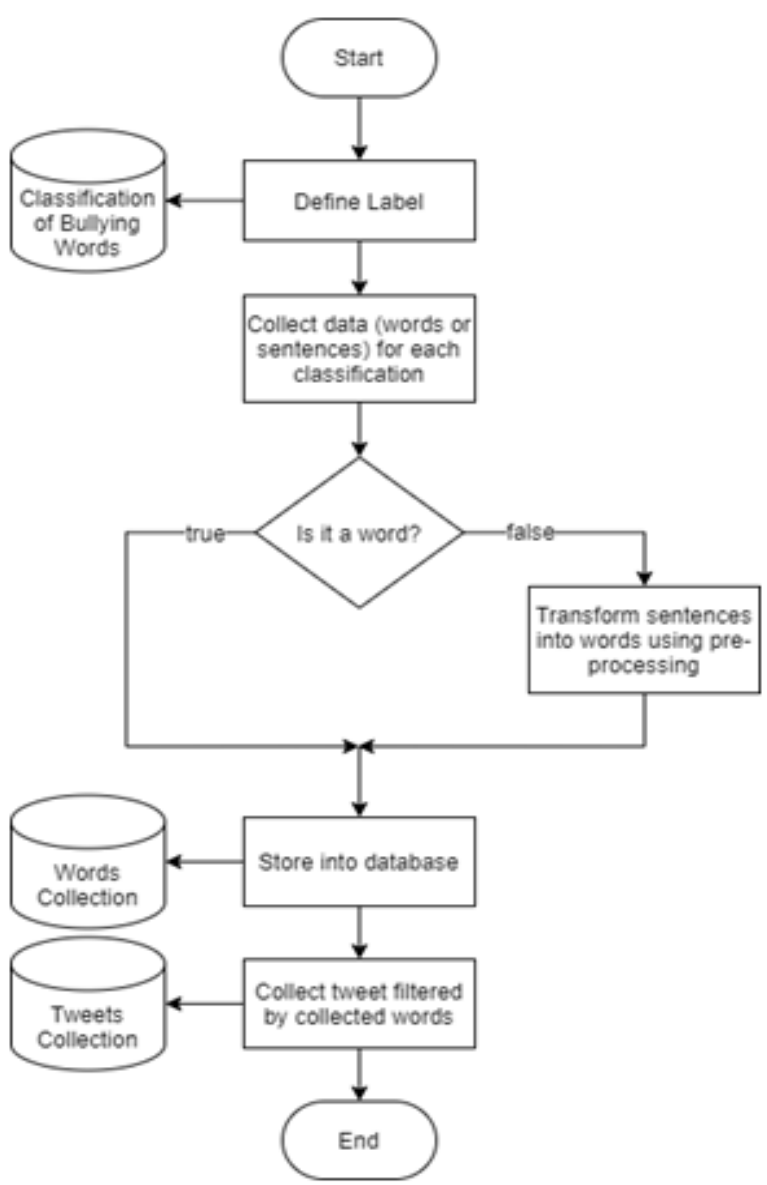

Figure 2: Flow of Data Determining

The Twitter crawling was done using RapidMiner application. RapidMiner supports twitter access token. Twitter data needed for this research are tweets containing the words (keywords) in TABLE 1. So, to get Twitter data we used operator "Search Twitter" in RapidMiner and filtered by every keyword. A total of 12,488 tweets were extracted between January $1^{\text {st }} 2020$ and December $31^{\text {st }}$ 2020, which is specifically contain Indonesian bullying words. The data are stored in Microsoft Excel format and recorded as in TABLE 2. The complete flow of data determining activity is depicted in Figure 2.

Before the data can be processed with a classification algorithm, the tweet collection needs to be pre-processed. This process involves cleaning, case folding, filtering from slang words and stop words, tokenizing, and stemming.
TABLE 2:

EAMPLE DATA IN EXCEL FORMAT

\begin{tabular}{|r|l|}
\hline Row Id & \multicolumn{1}{|c|}{ Text } \\
\hline 2 & $\begin{array}{l}\text { @ SilumanRi @ DhiaDemmy Kita yg sadar dan berakal } \\
\text { panik, gelisah, takut. Tapi buat mereka anjing penjilat } \\
\text { bangsat bangsa, no problem }\end{array}$ \\
\hline 13 & $\begin{array}{l}\text { @ squidwardfess jahat bgt anjir lu, kalo gabisa ngetik } \\
\text { something nice mending diem aje lu bangsat }\end{array}$ \\
\hline 7100 & $\begin{array}{l}\text { Kalo macet gausa klakson2! Emg tuh klakson bisa bikin } \\
\text { jalanan jd lancar?! Kampungan! }\end{array}$ \\
\hline
\end{tabular}

\section{A. Manual Labelling of Dataset}

Figure 3 show the steps of the proposed model. It shows how data tweets manually labelled. Each tweet will be identified the total number of occurrences of the word bullying from each label. From this stage, 5 values were obtained (1: total occurrences of bullying words related to animal label, 2: total occurrences of bullying words related to stupidity and psychology label, 3: total occurrences of bullying words related to disabled person label, 4: total occurrences of bullying words related to general bullying label, 5: the total occurrence of the word bullying related to bad attitude label). From these five values, the maximum value is chosen to determine the label for tweets. If the maximum value is in the total occurrence of the word bullying related to animal label, then the tweet is saved as a tweet labelled animal. The previous dataset amounted to 12,488 rows, after the labelling process, the number was reduced to 10,399 rows due to the process of eliminating noise.

The result of this manual labelling process is as shown in TABLE 3, where each tweet is labelled as animal, psychology and stupidity, disabled person, attitude, or general bullying.

TABLE 3:

MANUAL LABELING RESULT

\begin{tabular}{|r|l|l|}
\hline \multicolumn{1}{|c|}{ Id } & \multicolumn{1}{|c|}{ Text } & \multicolumn{1}{c|}{ Label } \\
\hline$\ldots$ & $\ldots$ & $\ldots$ \\
\hline 13 & $\begin{array}{l}\text { jahat banget anjing lebih } \\
\text { baik diam bangsat }\end{array}$ & Animal \\
\hline 4457 & bodoh tidak ada uang tolol & Stupidity and psychology \\
\hline 9748 & setan teman lebih baik mati & General bullying \\
\hline$\ldots$ & $\ldots$ & $\ldots$ \\
\hline
\end{tabular}




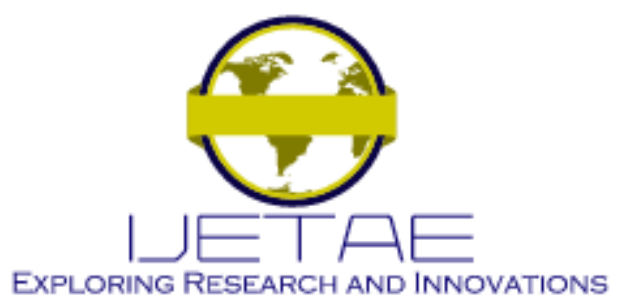

International Journal of Emerging Technology and Advanced Engineering

Website: www.ijetae.com (E-ISSN 2250-2459, Scopus Indexed, ISO 9001:2008 Certified Journal, Volume 11, Issue 10, October 2021)

After the dataset was pre-processed and manually labelled by following the guideline as shown in Figure 3, the dataset was processed to obtain prediction results using the Naive Bayes algorithm. In this stage, dataset divided into two parts, data for training and data for testing. This process was done by $\mathrm{k}$-fold cross validation, with the $\mathrm{k}$ value is 10. From this process, we got the amount of training data is 9359 and testing data is 1040 . With this data, Naïve Bayes generated the probability value of every class.

\section{B. Implementation of Nä̈ve Bayes Classifier}

The first process in Naïve Bayes is to find or calculate the probability for each class. The number of tweets with certain class divided by total of tweets in training data. Then, learn from training data with calculate the probability for each class of each tweet. The result of this calculation is as shown in TABLE 4. The Naïve Bayes calculation uses Laplace smoothing which functions to overcome the problem of zero probability [11]. The probability is calculated based on the number of occurrences of the attribute in a class and added by 1 as the Laplace value. The calculation result is then divided by the number of occurrences of an attribute plus 2 .
TABLE 4: NAÏVE BAYES CALCULATION WITH LOG-PROBABILITY

\begin{tabular}{|l|c|c|c|c|}
\hline \multicolumn{1}{|c|}{ Animal } & -0.0010 & -0.0003 & $\cdots$ & -0.0003 \\
\hline $\begin{array}{l}\text { Stupidity and } \\
\text { psychology }\end{array}$ & -0.0004 & -0.0004 & $\cdots$ & -0.0004 \\
\hline $\begin{array}{l}\text { Disabled } \\
\text { person }\end{array}$ & -0.0012 & -0.0006 & $\cdots$ & -0.0012 \\
\hline Attitude & -0.0155 & -0.0155 & $\cdots$ & -0.0155 \\
\hline General & -0.0010 & -0.1837 & $\cdots$ & -0.0003 \\
\hline
\end{tabular}

The result in TABLE 4 and TABLE 5 show minus value as it uses log-probability. The calculation uses logprobability to solve problems when it has many attributes [12][13]. If the probability value of each attribute is between 0 and 1 , when calculating it will get a very small value (close to 0 ) so that it cannot be represented in double or long double data types in the learning system. To get the probability results as log-probability, calculate the values with $l n$. With log-probability, the probability value is between $-\infty$ and 0 (has a larger range of values than 0 and 1). 


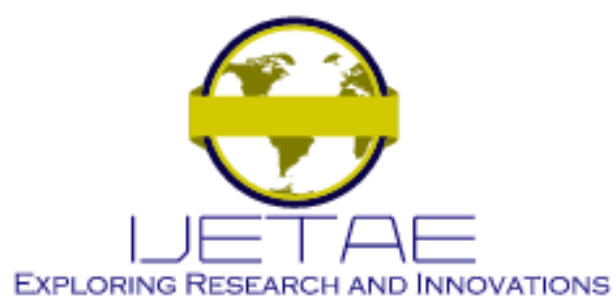

International Journal of Emerging Technology and Advanced Engineering

Website: www.ijetae.com (E-ISSN 2250-2459, Scopus Indexed, ISO 9001:2008 Certified Journal, Volume 11, Issue 10, October 2021)

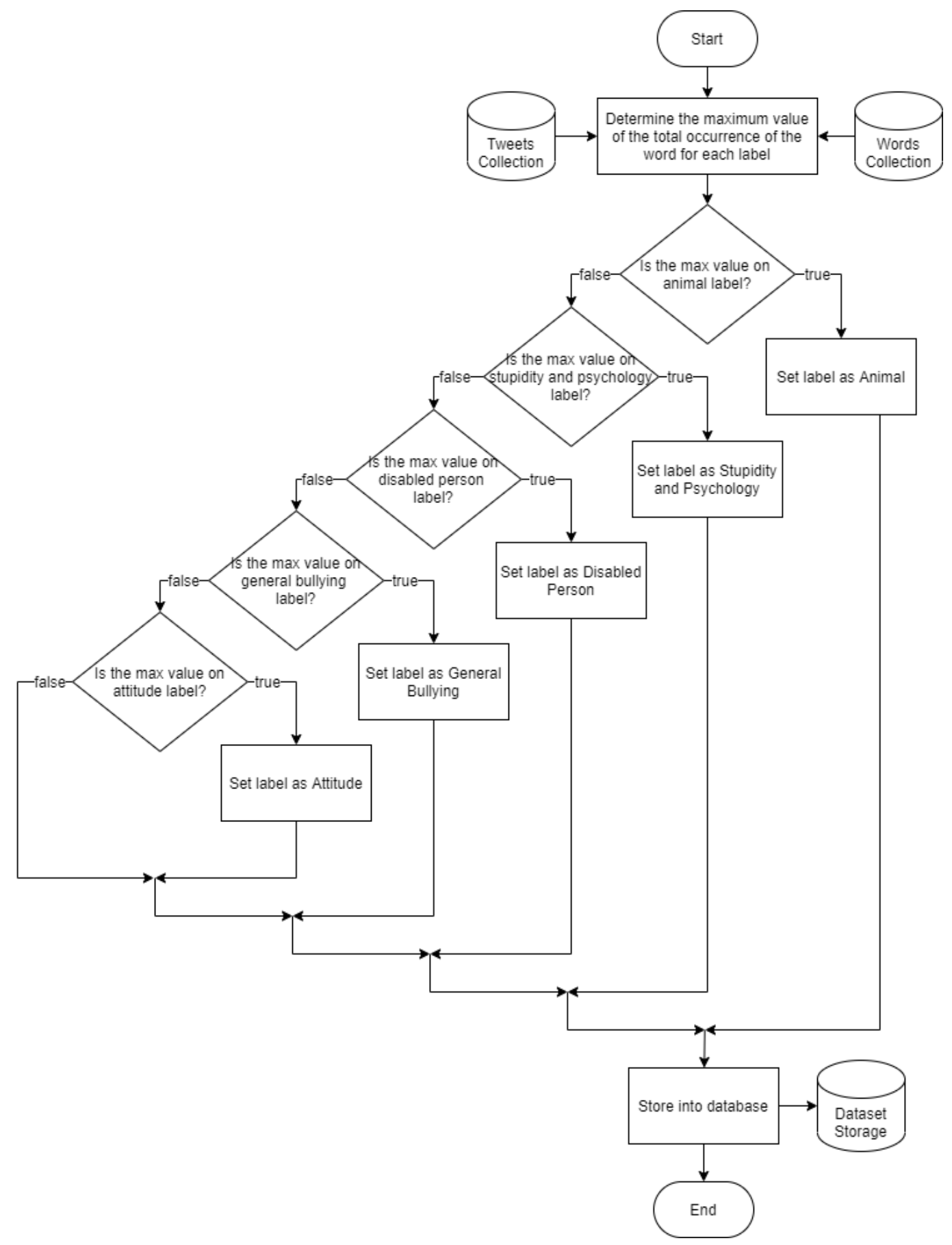

Figure 3: Flow of Manual Labeling 


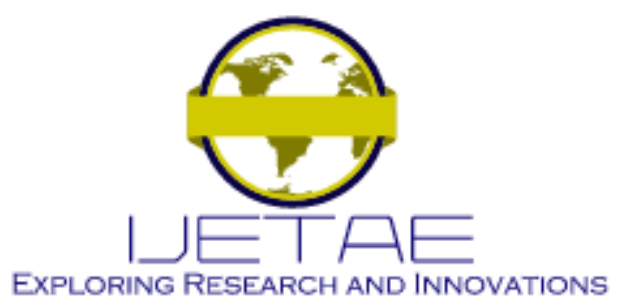

International Journal of Emerging Technology and Advanced Engineering

Website: www.ijetae.com (E-ISSN 2250-2459, Scopus Indexed, ISO 9001:2008 Certified Journal, Volume 11, Issue 10, October 2021)

TABLE 5:

NAÏVE BAYES PROBABILITY RESULT

\begin{tabular}{|r|r|r|r|r|r|}
\hline Id & $\begin{array}{c}\text { General } \\
\text { Bullying }\end{array}$ & Attitude & \multicolumn{1}{c|}{$\begin{array}{c}\text { Disabled } \\
\text { Person }\end{array}$} & $\begin{array}{c}\text { Psychology } \\
\text { and } \\
\text { Stupidity }\end{array}$ & \multicolumn{1}{|c|}{ Animal } \\
\hline$\ldots$ & $\ldots$ & $\ldots$ & $\ldots$ & $\ldots$ & $\ldots$ \\
\hline 13 & -44.548 & -105.098 & -45.870 & -43.979 & -31.735 \\
\hline 4457 & -35.176 & -96.359 & -36.477 & -27.210 & -30.778 \\
\hline 9748 & -26.343 & -96.359 & -35.946 & -35.342 & -31.434 \\
\hline$\ldots$ & $\ldots$ & $\ldots$ & $\ldots$ & $\ldots$ & $\ldots$ \\
\hline
\end{tabular}

TABLE 5 shows the final result of the calculation with Naïve Bayes, which is the probability result of testing data. The greatest probability value or the closest value to 0 determines the class prediction of the tweet data.

Based on the results of the Naive Bayes classification process on the entire testing data, the correctness of the dataset used was measured. This measurement is carried out by calculating the percentage of the total correct classification results divided from the total classification results. From this measurement, the result is $99.15 \%$ accuracy.

\section{Comparison with $k$-Nearest Neighbour Algorithm}

This model is also tested by implementing it using the kNN classification method. This comparison is to see which one has the better performance as done by [14][15]. In this test, the comparison is based on the accuracy of the results of both classification algorithms.

Experiments with the k-NN classification is performed using the KNIME tool. The dataset used is the same as that implemented with the Naïve Bayes classification algorithm. The process of separating the datasets is also the same, using the k-fold cross validation method, with the value of $\mathrm{k}$ is 10 .

TABLE 6:

COMPARISON OF NAÏVE BAYES WITH K-NN

\begin{tabular}{|l|l|}
\hline \multicolumn{1}{|c|}{ Name of Classifier } & $\begin{array}{c}\text { Evaluation Parameter } \\
\text { (Accuracy) }\end{array}$ \\
\hline Naïve Bayes & $99.15 \%$ \\
\hline k-NN & $99.85 \%$ \\
\hline
\end{tabular}

The experimental comparison of k-NN and Naïve Bayes are implemented through the performance measures of classification accuracy. The average accuracy obtained from this experiment with $\mathrm{k}-\mathrm{NN}$ is $99.85 \%$, as shown in TABLE 6 . The accuracy obtained is slightly higher than the Naive Bayes algorithm which is $99.15 \%$.

\section{CONCLUSION}

A model for classifying cyberbullying content with text mining conception has been developed and presented in this paper. The study produced the protocol for collecting dataset and labelling the dataset before they are used in the constructed model based on classification process using naive bayes algorithm. The results show that the proposed model can use to classify the cyberbullying content with $99,15 \%$ accuracy.

The process of detecting the negative posts involves five classes, including animal, psychology and stupidity, disabled person, attitude, and general bullying. From each of these classes, a total of 24 keywords were collected based on a literature study that was used as a reference for manual labelling process. This research can be adapted to research needs by adjusting or adding keywords used to sharpen the prediction results generated.

This model is only implemented for single language Indonesia and not applicable for other languages. So, this model can be improved by adding multi-lingual support to it for further work.

\section{REFERENCES}

[1] Y. Pratomo, “APJII: Jumlah Pengguna Internet di Indonesia Tembus 171 Juta Jiwa," Kompas, 2019. [Online]. Available: https://tekno.kompas.com/read/2019/05/16/03260037/apjii-jumlahpengguna-internet-di-indonesia-tembus-171-juta-jiwa. [Accessed: 16-Dec-2019].

[2] M. I. Zul, F. Yulia, and D. Nurmalasari, "Social media sentiment analysis using K-means and naïve bayes algorithm," Proc. - 2018 2nd Int. Conf. Electr. Eng. Informatics Towar. Most Effic. W. Mak. Deal. with Futur. Electr. Power Syst. Big Data Anal. ICon EEI 2018, no. February, pp. 24-29, 2018, doi: 10.1109/IConEEI.2018.8784326.

[3] M. Granik and V. Mesyura, "Fake news detection using naive Bayes classifier," 2017 IEEE 1st Ukr. Conf. Electr. Comput. Eng. UKRCON 2017 - Proc., pp. 900-903, 2017, doi: 10.1109/UKRCON.2017.8100379.

[4] I. Hariani; Riadi, "Detection of Cyberbullying on Social Media Using Data Mining Techniques,” Int. J. Comput. Sci. Inf. Secur. Vol. 15, No. 3, pp. 244-250, 2017.

[5] S. Sandberg, "Identifying Hateful Text on Social Media with Machine Learning Classifiers and Normalization Methods Using Support Vector Machines and Naive Bayes Algorithm," 2018.

[6] H. Margono, X. Yi, and G. K. Raikundalia, "Mining Indonesian cyber bullying patterns in social networks," Conf. Res. Pract. Inf. Technol. Ser., vol. 147, no. ACSC, pp. 115-124, 2014.

[7] R. B. Pramono and U. M. Kudus, "Cyber Bullying: Disconcerting Phenomenon in Indonesia , How Do We Respond?," no. March, 2018. 


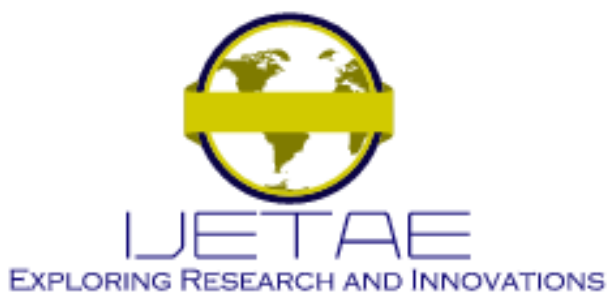

International Journal of Emerging Technology and Advanced Engineering

Website: www.ijetae.com (E-ISSN 2250-2459, Scopus Indexed, ISO 9001:2008 Certified Journal, Volume 11, Issue 10, October 2021)

[8] D. Berrar, "Bayes' theorem and naive bayes classifier," Encycl. Bioinforma. Comput. Biol. ABC Bioinforma., vol. 1-3, no. September, pp. 403-412, 2018, doi: 10.1016/B978-0-12-8096338.20473-1

[9] D. N. Utama, L. I. Lazuardi, H. A. Qadrya, B. M. Caroline, T. Renanda, and A. P. Sari, "Worth eat: An intelligent application for restaurant recommendation based on customer preference (Case study: Five types of restaurant in Tangerang Selatan region, Indonesia)," 2017 5th Int. Conf. Inf. Commun. Technol. ICoIC7 2017, no. May, 2017, doi: 10.1109/ICoICT.2017.8074654.

[10] D. N. Utama, Fitroh, Nuryasin, E. Rustamaji, Nurbojatmiko, and I. Qoyim, "D\&T: An Euclidean Distance Optimization based Intelligent Donation System Model for Solving the Community's Problem," J. Phys. Conf. Ser., vol. 801, no. 1, pp. 1-8, 2017, doi: 10.1088/1742-6596/801/1/012005.

[11] V. Cherian and B. MS, "Heart Disease Prediction Using Naïve Bayes Algorithm and Laplace Smoothing Technique," IJCST Eighth Sense Res. Gr., vol. 5, no. 2, pp. 67-73, 2017.
[12] D. Barber, "Learning from Data 1 Naive Bayes," 2004. [Online]. Available:

http://users.cecs.anu.edu.au/ daa/courses/GSAC6017/naivebayes.pd f. [Accessed: 20-Jun-2021].

[13] J. Malviya, V. Patel, and A. Srivastava, "New Naïve Bayes Classifier for Improve Intrusion Detection System Accuracy," pp. 7$11,2017$.

[14] M. Irfan, W. Uriawan, O. T. Kurahman, M. A. Ramdhani, and I. A. Dahlia, "Comparison of Naive Bayes and K-Nearest Neighbor methods to predict divorce issues," IOP Conf. Ser. Mater. Sci. Eng., vol. 434, no. 1, 2018, doi: 10.1088/1757-899X/434/1/012047.

[15] R. Devika, S. V. Avilala, and V. Subramaniyaswamy, "Comparative study of classifier for chronic kidney disease prediction using naive bayes, KNN and random forest," Proc. 3rd Int. Conf. Comput. Methodol. Commun. ICCMC 2019, no. Iccmc, pp. 679-684, 2019, doi: 10.1109/ICCMC.2019.8819654. 